\title{
Developing Home Service System: Business Process Reengineering for Motorcycle Workshop
}

\author{
Y Windarto ${ }^{1}$, R Hersant ${ }^{2}$, E Putro ${ }^{3}$ \\ ${ }^{1,2,3}$ Study Program of Information System, Krida Wacana Christian University, \\ Jakarta, Indonesia
}

E-mail: yudhi_yk@ukrida.ac.id¹, rebecca2015si010@civitas.ukrida.ac.id ${ }^{2}$, endiputro@ukrida.ac.id ${ }^{3}$

Submitted: 21 January 2021, revised: 11 February 2021, accepted: 16 February 2021

\begin{abstract}
Abstrak. Organisasi Bisnis selalu berusaha untuk mencapai keberlanjutan bisnis. Terdapat berbagai tantangan dalam lingkungan bisnis yang dinamis yang harus direspon oleh setiap organisasi. Respon organisasi sangat menentukan keberlangsungan bisnis organisasi di masa depan. Untuk saat ini, dalam situasi pandemi Covid 19, setiap organisasi harus kreatif dan inovatif untuk mengubah dan memodifikasi model bisnisnya agar dapat bertahan. Bengkel sepeda motor merupakan salah satu Usaha kecil-menengah (UKM) yang terdampak pandemi Covid 19, karena kebijakan pemerintah yang membatasi aktivitas masyarakat dan menjaga jarak. Menurunnya pelanggan bengkel sepeda motor dan merespon situasi tersebut memunculkan ide untuk melakukan rekayasa model bisnis. Sistem pelayanan rumah dipilih sebagai solusi untuk berjuang dalam situasi ini, tentunya dengan menerapkan protokol kesehatan yang baik. Sistem ini dibangun dengan aplikasi mobile sebagai alat bantu dalam melakukan pendaftaran dan pengelolaan jadwal layanan pelanggan. Dengan sistem ini pelanggan tidak perlu lagi datang dan mengantri di bengkel sehingga lebih aman dalam situasi pandemi ini. Tidak semua layanan dapat dilayani dengan sistem ini, hanya perbaikan kecil, sedang dan rutin yang dapat dilayani dengan sistem ini. Proses transaksi pembayaran dilakukan di tempat sesuai dengan kalkulasi oleh sistem. Dengan model proses bisnis baru ini, diharapkan menjadi solusi yang tepat bagi konsumen dan bengkel agar tetap produktif di tengah pandemi Covid 19.
\end{abstract}

Kata kunci: aplikasi mobile; home service; bengkel; rekayasa proses bisnis.

\begin{abstract}
Business organizations always strive to reach business sustainability. There are various dynamic challenges in business environment that must be responded by each organization. Organizational responses for each challenge are very decisive to organization's business sustainability in the future. In this Covid19 pandemic situation each organization must be creative and innovative to change and modify their business model to survive. Motorcycle workshop is one of the Small-Medium Enterprise (SME) affected by Covid19 pandemic, because of the policy to restrict activity and to apply social distancing. Decreasing customers of motorcycle workshop brings up the idea to reengineering business model as a response to the situation. Home service system was selected as an alternative solution to survive in this situation by implementing a good health protocol. This system was built in a mobile application as a tool for reservation to manage customers' service schedules. With this system, customers do not have to come and queue at the workshop, so it will be safer in this pandemic situation. However, not all services can be served with this system. Only can minor, moderate, and routine repairs be served with this system. The payment transaction process is carried out on the spot according to the calculations by the system. With this new business
\end{abstract}


process model, it is hoped that it will be the right solution for customers and the workshop to remain productive in the midst of the Covid19 pandemic.

Keywords: mobile application; home service; motorcycle workshop; business process reengineering.

\section{Introduction}

Today is a tough situation for most people around the world because of the impact of the Covid19 pandemic. Health problems and the slowing economy have become challenges that spread to various aspects of human life [1]. Many efforts, creativity and innovation have been done to survive in this uncertain condition. In line with various efforts to adjust with the era of the 4.0 industrial revolution, this situation also makes people follow the trend to take advantage of information and communication technology, especially the use of the internet of things, cloud computing technology and application in all existing business models [2][3][4][5]. Last year, Japan even introduced Roadmap Society 5.0 which seemed more humanist because it introduced the term cyber physical human system and super smart society where human is the center and that makes Information and Communication Technology (ICT) a part of human daily activities [6].

At the implementation level, organizations have to look at the real problems and solutions that can be taken to survive in the current bad situation. There are many problems around organization that must be solved in order to manage the sustainability [7][8]. Small and medium enterprises (SME) that exist today need to rack their brains to innovate, modify and reengineer their business processes or models in order to survive[9]. They must identify dan understand new business values for customer [10][11][12]. The best way to survive is to not only think about internal organization but also every stakeholder associated with our business [1].

Terang motor is a motorcycle workshop in Tangerang, Banten, Indonesia. The workshop provides motorcycle repair services and selling vehicle spare parts. Currently Terang Motor has been affected by the Covid19 pandemic. Social restriction policies and social distancing have affected to the decline iof customers and revenue. This problem must be addressed immediately so that the motorcycle repair service business can continue to run and the organization can survive in this difficult time [11].

In order to respond this condition, Terang Motor workshop tried to apply business process reengineering by creating a home service model using application to make reservations and to manage repair schedules. This solution is considered appropriate because it will minimize customers' queues at the repair shop. The home service model will also be attractive to consumers because they do not need to leave the house, but technicians come to their homes without leaving behind the health protocols.

The purpose of this research is to develop an Android-based application for the reservation and management of the operational schedule for the home service system at the Terang Motor Workshop. Although not all types of motorcycle repair services can be done with this home service model, it will be very helpful for the workshop to run the business and costumers to receive motorcycle repair services without leaving their house.

\section{Theoretical Framework}

Business Process Reengineering (BPR) is defined as radical redesign of processes to gain significant improvements in performance, cost, quality, and services as seen in Figure 1. It is a renewal of business process to create new values of the business processes. The advantage values from BPR processes make the business more effective \& efficient [7][11]. 


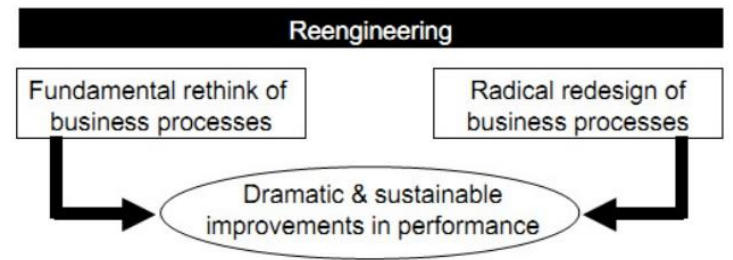

Figure 1. Business Process Re-engineering Model

From literature studies, there is some research related to development home service \& reservation systems. Manda developed e-Setor (Electronic Service Motor, web based application using Yii2 framework [13]. Widhiananda developed motorcycle service reservation application based on website [14]. Giyan developed web application for spare part of motorcycle selling and reservation to repair. Litasari and Ngurah I Gusti developed web based application to book services system for motorcycle [15][16]. Budiono in his paper discussed the business process reengineering by optimizing processes and procedures for the sale of spare parts, warehouse management and shortening service time [11].

\section{Research Method}

This study applies the method of system development using waterfall model as seen in Figure 2. There are several steps such as requirement analysis, system design, construction and implementation, testing, and deployment and maintenance.

The system requirement and analysis of this study were done through observation, interview, and literature study. Then, requirement proceeded with application development based on the system design that referred to the analysis results. The final stage was testing, deployment, and maintenance [17].

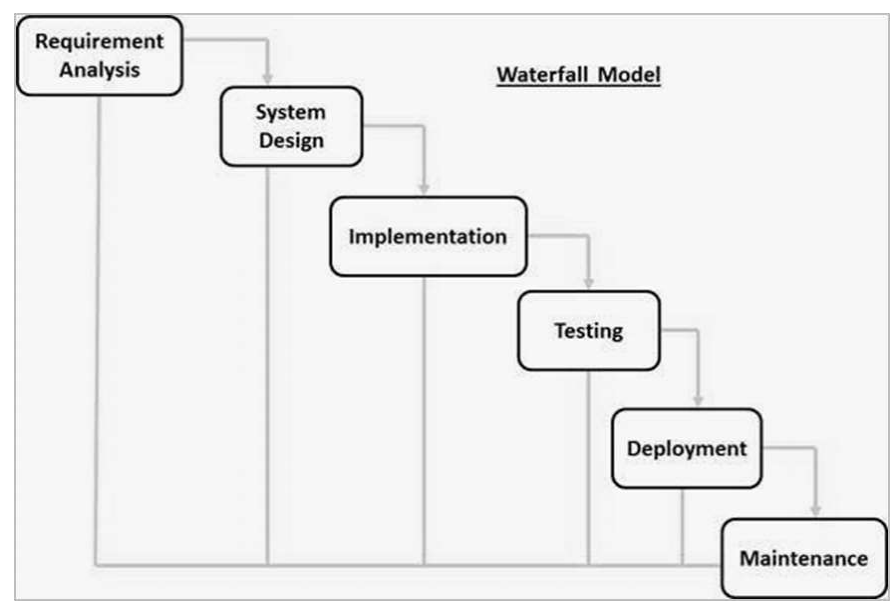

Figure 2. Waterfall model

\section{Analysis \& Design}

From the results of observations, interviews, and literature studies, it was obtained an overview of the motorcycle repair service process that is currently running. From the procedures, there were no technical problems. However, due to the Covid19 pandemic situation, the number of customers who came to the workshop dropped significantly up to almost 50\% from normal condition.

The Business Process Reengineering at the Terang Motor Workshop was carried out because it responded to the problem that occurred in pandemic Covid19 situation. In these conditions the health 
protocol must be carried out so that queues and crowds should be avoided. Workshop activities that invite queues and crowds should be regulated so that customers can maintain their distance from each other. This has resulted in the decrease of customers and the income of the workshop.

The idea of home service is based on the potential and capability to carry out services to consumer's homes, so the risks of queues and crowds can be suppressed. In this new design process, a mobile application will be developed to handle reservation and operation management of home service process. Here are some advantages and disadvantages of the proposed home service business process.

Advantages:

1) Customers feel happy because they can choose their own schedule

2) The workshop admin is greatly assisted in managing the operation of the workshop with the home service application

3) Health protocol will be easier to implement

4) Daily work is clearer because it has been previously scheduled

5) All operational data and transactions are recorded properly

Disadvantages:

1) Not all types of repairs can be done by home service

2) The conditions at the customer's house vary. It is sometimes not representative for motorcycle repair work.

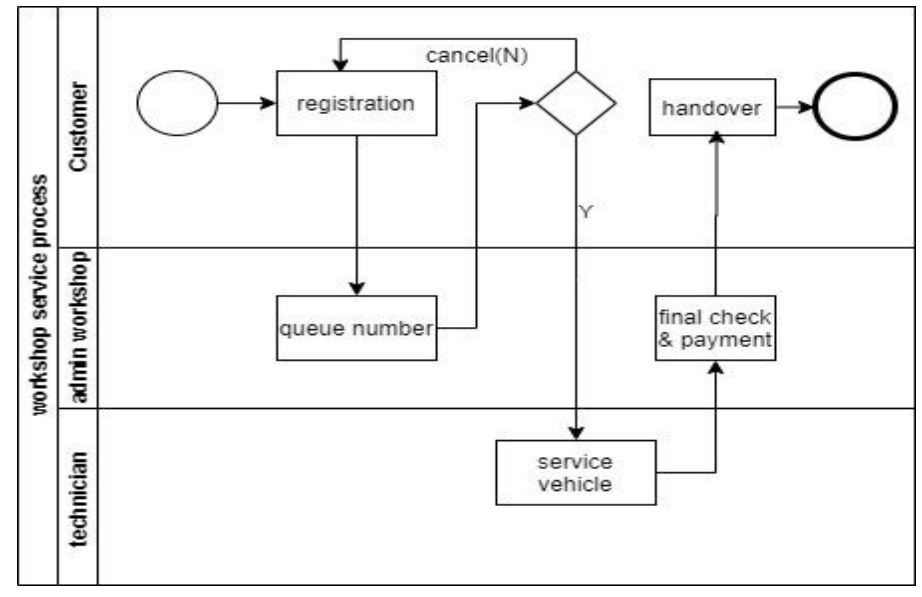

Figure 3. Current Business Process on Workshop

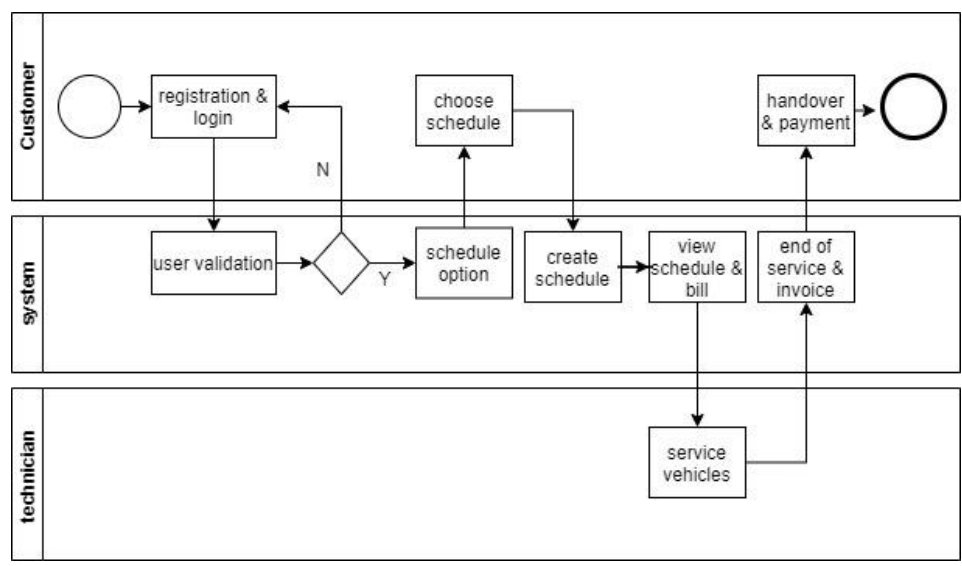

Figure 4. Proposed Business Process of Home Service 
The swimlane diagrams show the current business process as seen in Figure 3 and the proposed home service business process in Figure 4. With the home service application, it will be very helpful for the workshop admin to manage the schedule and workshop operations. Customers will find it effective because they do not need to queue or to go to the workshop. For workshop technicians, they know the schedule and the workload that must be done every day because everything has been scheduled on system.

Here is a use case diagram of the home service application in the motorcycle workshop. There are 3 user roles namely admins, customers, and technicians. Customers can perform various features such as create account, login/logout, edit profile, reservation and view schedule and history. Meanwhile, the technician can login/logout, view schedule, and add service option as seen in Figure 5.

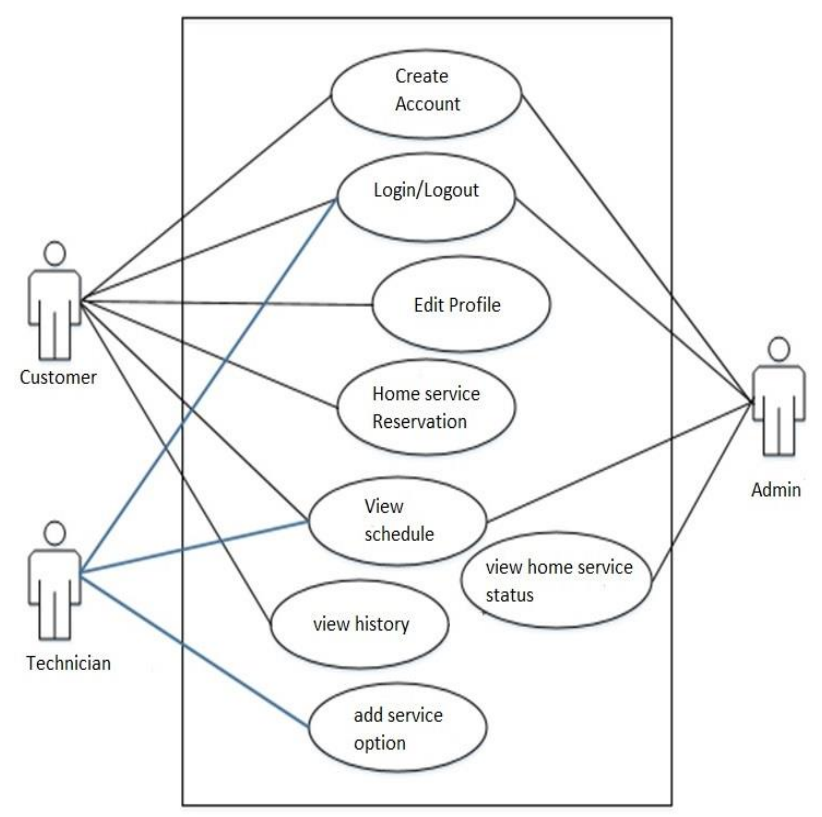

Figure 5. Use case Diagram of home service Apps

The following is an activity diagram that illustrates the user login as seen in Figure 6 and the reservation process as seen in Figure 7. 


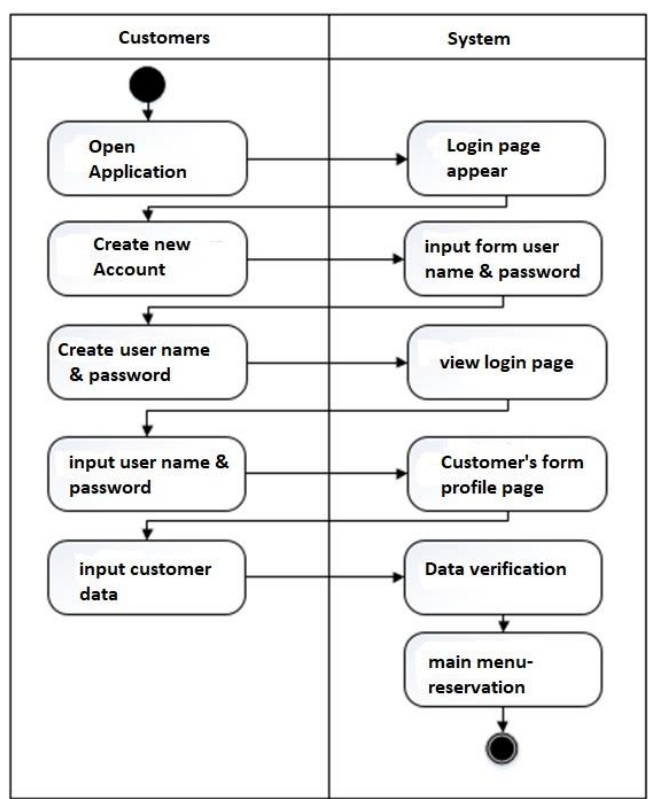

Figure 6. Activity diagram user login

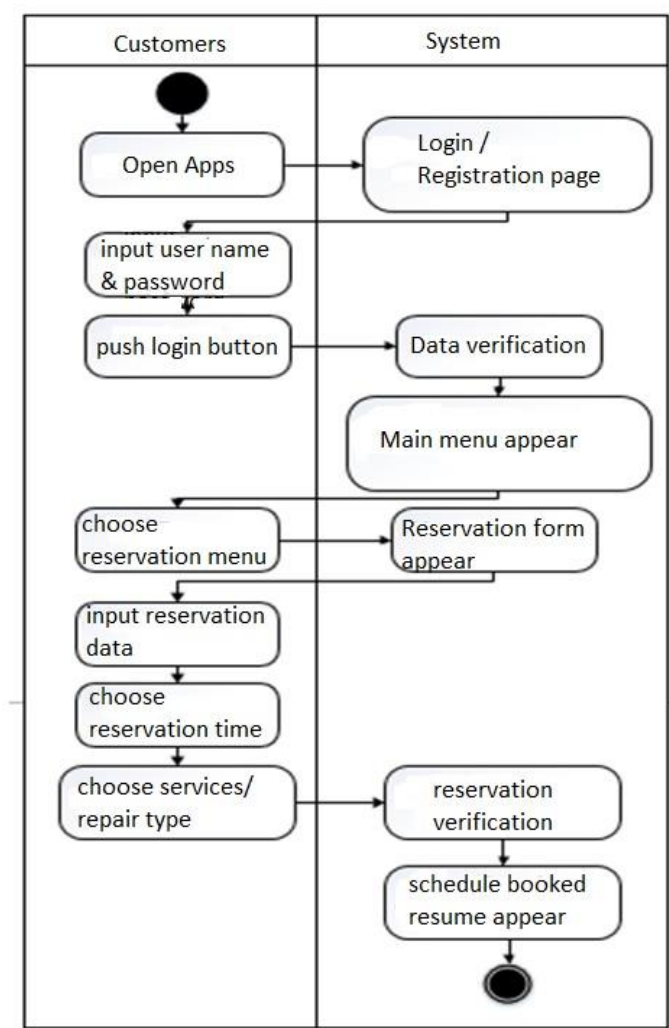

Figure 7. Activity Diagram user reservation

\section{Result and Discussion}

The results of the application process design for the Terang Motor Home Service application are implemented in an android smartphone with the minimum requirements of Android 4.0 Ice Cream Sandwich. The following is the display of Terang Motor Home Service Application.

\subsection{Splash Screen \& User Login}

When opening Terang Motor Home Service application, a splash screen will appear. Then, the user can login or register in the registration page. On the login/registration page, those who have an account can login directly, but for the first timer, users have to register by clicking the "Buat Akun".

There are three categories of users in this application namely admin, customer, and technician. Users can enter the page according to their roles as seen in Figure 8.
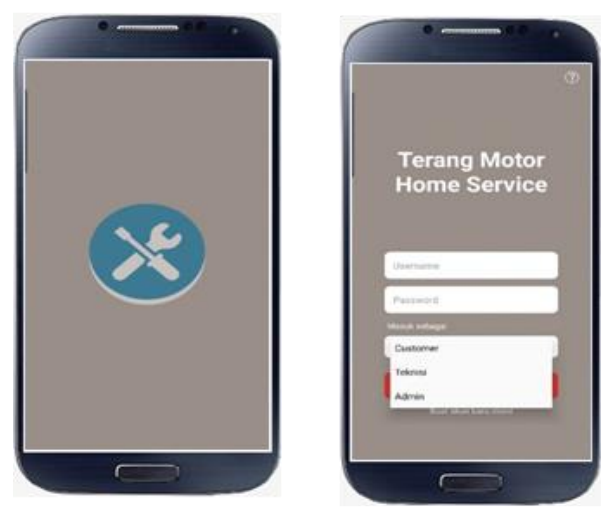

Figure 8. View splash screen \& Login page. 


\subsection{Customer view pages}

When logging in as a customer to the main page, the customer will view the main page with the display of a personalized customer name and address. As seen in Figure 9, the main page will show the menus of Profile, Reservations, History and Repair Schedules.
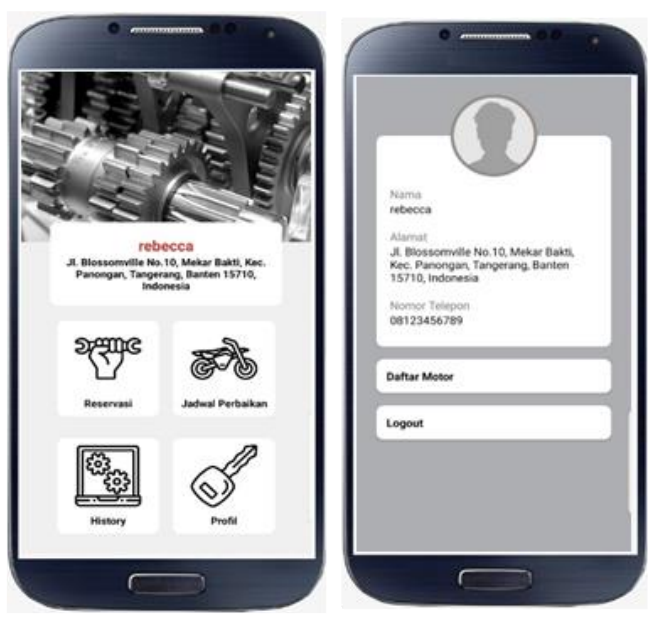

Figure 9. Main menu and Customers profile page.
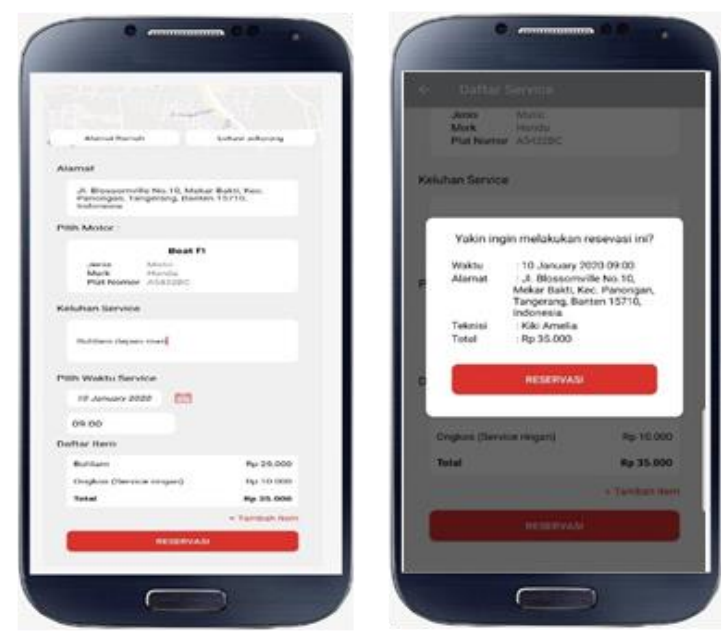

Figure 10. Customer Reservation page.

1) Profile menu is a menu for users to add customer profile data. Profile data includes name, address, telephone number, and motorcycle data. Customers can register more than one vehicle. The vehicle data to be input includes the vehicle number, the frame and the engine number, the type of vehicle, and the year of manufacture.

2) Reservation menu is a menu where customers can make reservations for home services. In this menu the customer can register the motorcycle to be serviced, inform the type of repairs, and determine the schedule for the home service. The schedule for implementing the home service can be selected from the schedule slots that are still empty from the availability of 5 slots per day. The schedule that has already been filled in cannot be selected.

3) History menu is a menu to view the history of home services that have been done previously. With this history the customer can schedule the next routine service according to the provisions.

4) Repair schedule menu is a menu where customers can see the schedule of home services, that will be implemented soon. Admin will confirm the day before the scheduled service via telephone to ensure the implementation of home services. In the reservation process, the customer can register the motorcycle to be repaired, inform the type of repair, and state the complaints to the workshop. Besides that, the customer can choose the schedule, the day, and the hour as long as the schedule has not been booked by someone else. In this process the customer can also immediately see the estimated cost of repairing the vehicle that will be billed, because each type of service and spare part has a price range. By pressing the reservation button, the home service reservation process has been scheduled as seen Figure 10. 


\subsection{Admin view pages}

On the admin side, after logging in into the application, the main page or admin dashboard will appear. On this page there are menus of "Rekap Pelanggan"(customers list), "Rekap Teknisi" (technicians list), "Tambah Pelanggan" (add customers) and "Tambah Teknisi" (add technicians) as seen in Figure 11.

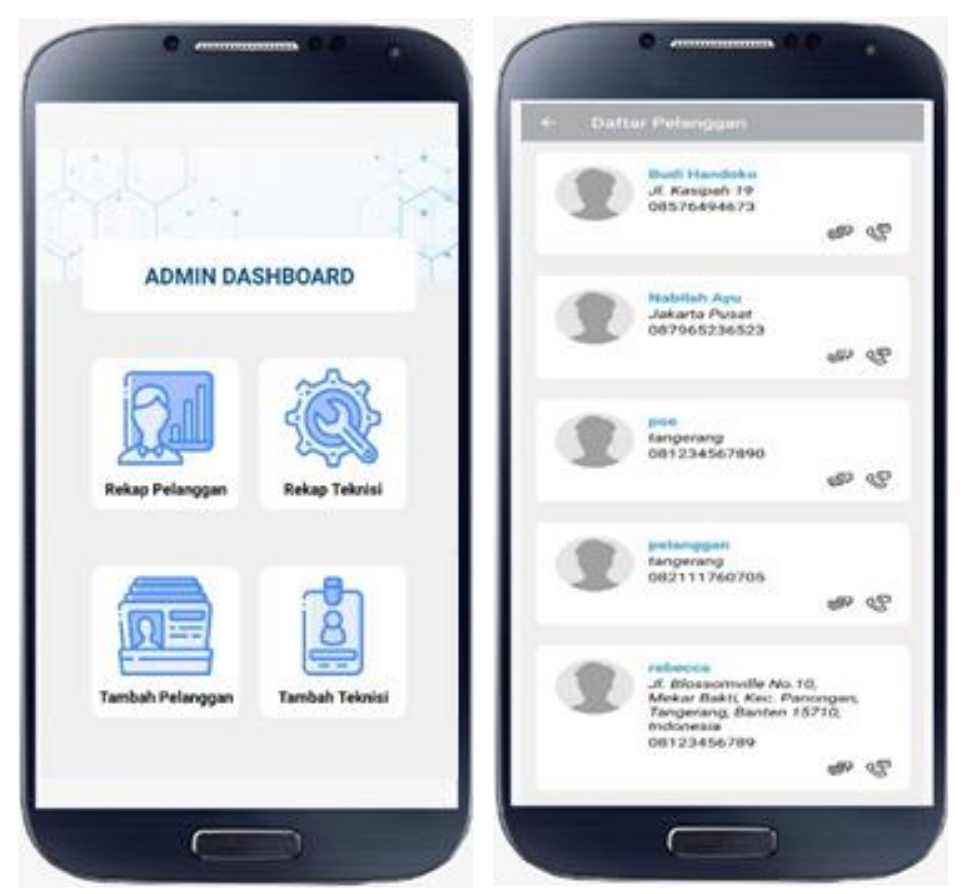

Figure 11. Admin dashboard and Customer list page

1) Rekap Pelanggan menu displays the customer list page, where the admin can further view the transaction history of each customer.

2) Rekap Teknisi menu displays technician list data and the admin can view the history of work that has been done from each technician.

3) Tambah Pelanggan menu is a menu where admin can add new customers.

4) Tambah Teknisi menu is a menu where admin manages technician data.

The admin has a role to thoroughly monitor the home service processes that are carried out, starting from managing and monitoring reservation data, changing or cancelling schedules, providing reminders to customers and technicians, and monitoring every completed process to validate and send home service bill to customer. In this case the admin role is performed by the workshop manager or workshop owner. The menu of adding customer and technician also allows admins to manage customer and technician data, although customers or technicians can register themselves. The history of customer transactions will make it easier for the admin to make workshop financial reports, make technician commission calculations, and monitor the availability of the spare parts. 


\subsection{Technician view pages}

The technician main page will show the personal technician's main page, which only displays technician data, service menu, schedule, and history [Fig. 12].
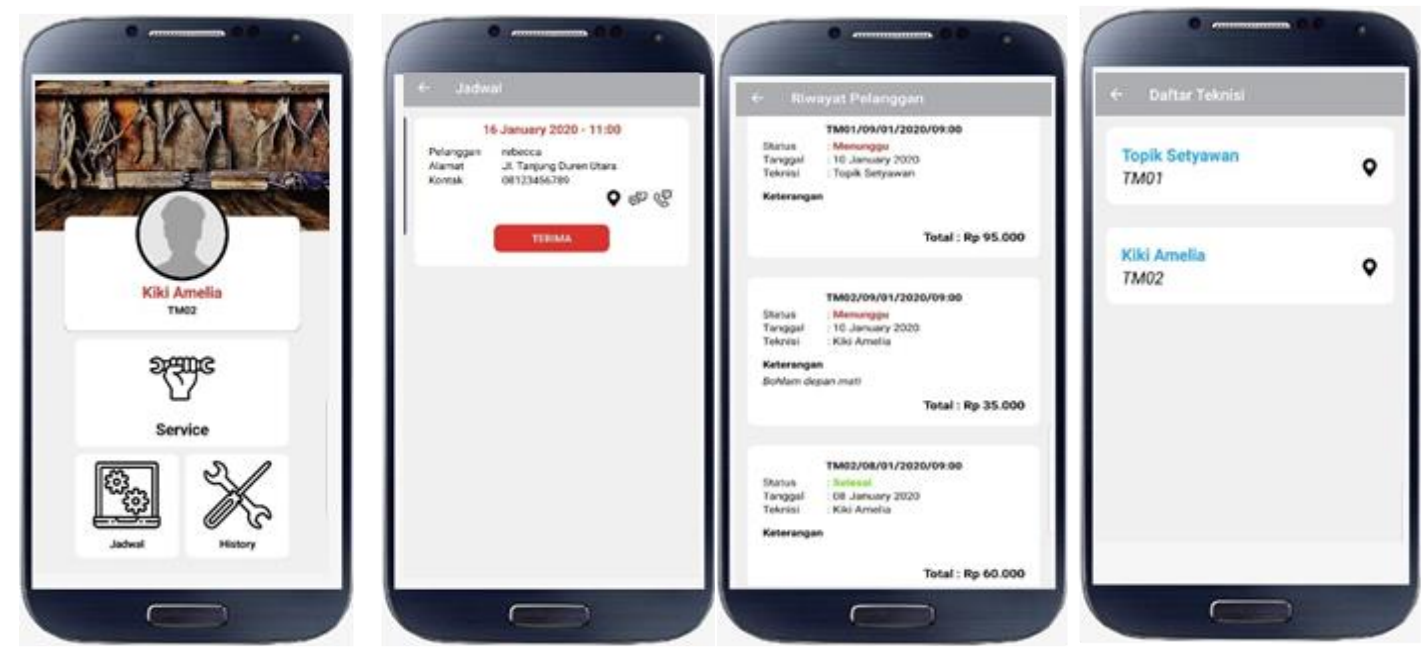

Figure 12. Technician's Main page and Service Order page

1) Schedule menu displays the incoming reservation orders. The technicians can accept them by pressing the accept button.

2) Service menu displays a list of home service schedules that have been agreed upon for a home service visit

3) History menu displays reports on the implementation of home services that have been carried out by technicians

The application of Terang Motor home service is useful for monitoring the incoming orders and receiving home service schedules from customers. Each technician has their own service area so they will only accept customer orders with address according to their region. With the system, the technician's visit process will be more effective and efficient.

A technician can input data in adding details of the service process, because customers often ask for other services that are not included in the previous reservations. In the service detail page, there is an edit invoice menu that allows technician to add several service options as requested by the customers. Of course, the additional costs incurred will be added directly to the billing of the customer.

In their work, technicians are at the forefront of meeting customers directly. Each technician is equipped with tools and spare parts that are often needed by customers, or special ones depending on the type of service agreed upon.

After the repair process is completed, the technician will press the "finished" button, so that the service details will be recorded as a transaction history. Then, the customer will make a payment to the technician according to the bill that appears in the customer's history as seen in Figure 12.

The testing and evaluation process was carried out using black box testing that is done by the internal team to test system functionality. The result was that all functions for all user categories, admins, technicians, and customers worked properly. For further research, it is possible to survey the users directly using the appropriate user experience evaluation method. 


\section{Conclusion}

Business process reengineering with the development of Home Service applications at the Terang Motor workshop has provided added value for most of the stakeholders involved, including workshop owners, admins, technicians, and customers. For workshop admins, this application is very useful because it helps manage the daily operations of the workshop and make it easier to manage data. For technicians, it provides a clear and scheduled daily workload. Moreover, it eases the customers to choose a schedule and to repair vehicles without leaving their home. The home service system is the right solution in this Covid19 pandemic because it can minimize queues or crowds. In addition, the business can still run without ignoring the health protocol.

\section{References}

[1] J. Sheth, "Business of business is more than business: Managing during the Covid crisis," Ind. Mark. Manag., vol. 88, no. June, pp. 261-264, 2020, doi: 10.1016/j.indmarman.2020.05.028.

[2] Z. R. Alashhab, M. Anbar, M. M. Singh, Y.-B. Leau, Z. A. Al-Sai, and S. Abu Alhayja'a, "Impact of coronavirus pandemic crisis on technologies and cloud computing applications," $J$. Electron. Sci. Technol., no. August, p. 100059, 2020, doi: 10.1016/j.jnlest.2020.100059.

[3] N. A. Risso et al., "A cloud-based mobile system to improve respiratory therapy services at home," J. Biomed. Inform., vol. 63, pp. 45-53, 2016, doi: 10.1016/j.jbi.2016.07.006.

[4] V. Astarita, D. C. Festa, and V. P. Giofrè, "Mobile Systems applied to Traffic Management and Safety: A state of the art," Procedia Comput. Sci., vol. 134, pp. 407-414, 2018, doi: 10.1016/j.procs.2018.07.191.

[5] C. Shao, H. Yang, Y. Zhang, and J. Ke, "A simple reservation and allocation model of shared parking lots," Transp. Res. Part C Emerg. Technol., vol. 71, pp. 303-312, 2016, doi: 10.1016/j.trc.2016.08.010.

[6] H. Andriyanto, "Di Era Industry 4.0, Jepang Sudah Masuk Society 5.0," Beritasatu.com, 2019. https://www.beritasatu.com/ekonomi/534519/di-era-industry-40-jepang-sudah-masuk-society50 (accessed Jan. 08, 2021).

[7] M. AbdEllatif, M. S. Farhan, and N. S. Shehata, "Overcoming business process reengineering obstacles using ontology-based knowledge map methodology," Futur. Comput. Informatics J., vol. 3, no. 1, pp. 7-28, 2018, doi: 10.1016/j.fcij.2017.10.006.

[8] A. Omidi and B. Khoshtinat, "Factors Affecting the Implementation of Business Process Reengineering: Taking into Account the Moderating Role of Organizational Culture (Case Study: Iran Air)," Procedia Econ. Financ., vol. 36, no. 16, pp. 425-432, 2016, doi: 10.1016/s2212-5671(16)30058-2.

[9] S. Pattanayak and S. Roy, "Synergizing Business Process Reengineering with Enterprise Resource Planning System in Capital Goods Industry," Procedia - Soc. Behav. Sci., vol. 189, pp. 471-487, 2015, doi: 10.1016/j.sbspro.2015.03.194.

[10] Y. Borgianni, G. Cascini, and F. Rotini, "Business Process Reengineering driven by customer value: A support for undertaking decisions under uncertainty conditions," Comput. Ind., vol. 68, pp. 132-147, 2015, doi: 10.1016/j.compind.2015.01.001.

[11] A. Budiono and R. Loice, "Business Process Reengineering in Motorcycle Workshop X for Business Sustainability," Procedia Econ. Financ., vol. 4, no. Icsmed, pp. 33-43, 2012, doi: 10.1016/s2212-5671(12)00318-8.

[12] F. De Felice and A. Petrillo, "Optimization of Automotive Glass Production through Business Process Reengineering Approach," Procedia - Soc. Behav. Sci., vol. 75, pp. 272-281, 2013, doi: 10.1016/j.sbspro.2013.04.031.

[13] M. Sari and N. Dwiyani, "PERANCANGAN APLIKASI E-SETOR ( ELECTRONIC SERVICE MOTOR ) MENGGUNAKAN YII2 FRAMEWORK BERBASIS RESTFUL WEBSERVICE Manda Sari 1), Nurindah Dwiyani 2) 1," J. Vokasional Tek. Elektron. dan Inform., vol. 7, no. 2, pp. 56-60, 2019, [Online]. Available: http://ejournal.unp.ac.id/index.php/voteknika/article/view/104196/101746.

[14] I. G. N. A. Widhiananda, I. M. Arsa Suyadnya, and K. Oka Saputra, "Rancang Bangun 
Aplikasi Reservasi Service Untuk Bengkel Sepeda Motor Berbasis Web," J. SPEKTRUM, vol. 4, no. 2, p. 97, 2018, doi: 10.24843/spektrum.2017.v04.i02.p13.

[15] M. L. Sestiayunda and F. P. H, "Pengembangan Sistem Informasi Booking Service Motor Honda Pada Pt. Pacific Motor Ii Bekasi Berbasis Web," J. Inkofar, vol. 41, no. 2, pp. 84-93, 2017.

[16] G. Eko, Y. Yunita, and H. Amalia, "Rancang Bangun Sistem Informasi Pelayanan Jasa Home Service Dengan Model Waterfall Pada CV. Gian Motor Autoservice," J. Perspekt., vol. 17, no. 1, pp. 17-21, 2019, doi: 10.31294/jp.v17i1.5195.

[17] R. S. Pressman, Software Engineering; a practitioner's approach, 5th ed. McGraw-Hill Higher Education, 2001. 